\title{
ANALISIS PENGARUH HARGA JUAL TERHADAP VOLUME PENJUALAN MOBIL KIJANG INNOVA Vi PADA AUTO 2000 DI BANDAR LAMPUNG
}

\author{
Meilinda Safitri ${ }^{(1)}$, Azizi Ridho $^{(2)}$ \\ Fakultas Ekonomi Universitas Sang Bumi Ruwa Jurai \\ meilinda.safitri@fe.saburai.ac.id,ridho_azizi95@gmail.com
}

\begin{abstract}
Abstrak. PT. AUTO 2000 Cabang Tanjung Karang merupakan salah satu perusahaan yang bergerak di bidang pemasaran mobil jenis kendaraan mobil . Masalah yang di hadapi PT. AUTO 2000 Bandar Lampung adalah terlihatnya pencapaian target penjualan yang tidak memuaskan dan penjualan berfluktuasi cenderung menurun dengan rata-rata $91 \%$ persemester dan realisasi penjualan yang menunjukkan penurunan dengan rata-rata sebesar 78,99\% persemester,permasalahannya adalah bagaiman pengaruh harga jual mobil kijang Innova Vi terhadap volume penjualan mobil kijang Innova Vi pada PT. AUTO 2000 di Bandar Lampung. Tujuan penulis ini adalah untuk mengetahui berpengaruh harga jual terhadap volume penjualan mobil kijang Innova Vi pada PT. AUTO 2000 di Bandar Lampung. Hipotesis yang di ajukan adalah volume penjualan mobil kijang Innova Vi pada PT. AUTO 2000 di Bandar Lampung di pengaruhi secara negatif oleh harga jual. Metode penelitian yang di gunakan adalah penelitian kepustakaan dan penelitian lapangan melalui observasi dan dokumentasi.
\end{abstract}

Kata Kunci : Harga jual, Volume penjualan, Perusahaan.

\section{PENDAHULUAN}

Permintaan adalah keinginan akan suatau produk yang didukung dengan kemampuan serta kesediaan membelinya. Kendaraan mobil sebagai salah satu alat angkut darat mempunyai peranan yang penting bagi masyarakat . Perusahaan AUTO 2000 di Bandar Lampung, memasarkan produk mobil kijang berdasarkan pada pemesanan yang datang dari konsumen. Produk mobil kijang ini di jual pada konsumen melalui pada pertimbangan-pertimbangan tertentu. Jenis kendaraan mobil kijang yang di pasarkan oleh AUTO 2000 adalah salah satu produk yang di tawarkan dengan omzet penjualan yang baik, dan di harapkan dapat meningkatkan volume penjualan. Setiap produk yang ditawarkan perusaan harus didukung oleh kegiatan pemasaran yang efektif, karena keberhasilan suatu perusahaan sangat tergantung pada aktifitas $\begin{array}{lrr}\text { pemasarananya. } & \text { Mepasaran } & \text { juga } \\ \text { merupakan suatu } & \text { kegiatan } & \text { saling } \\ \text { mempengaruhi dari suatu } & \text { bauran } \\ \text { pemasaranan yang terdiri dari } & \text { produk, }\end{array}$ harga, promosi dan saluran distribusi.

Pengertian pemasaran menurut philip ( 2014 : 13 ) "Pemasaran adalah semua kegiatan yang tertujuan untuk memperlancar arsu barang/jasa dari produksi ke konsumsi secara paling efesien denfan maksud untuk menciptakan permintaan efektif."

Tujuan didirikanya perusahan ini adalah mencari keuntungan agar kelangsungan hidup perusaan akan terjamin. Selian itu memberikan sambungan positif bagi masyartakat maupun pemerintah. Jika perusaan dapat meningkatkan penjualannya, maka perusahaan dapat meningkatkan laba. Untuk itu kegiatan pemasaranan yang dilakukan oleh PT .AUTO 2000 dalam memasarkan mobil adalah sebagai berikut : 
Tabel 1. Merk Kendaraan Jenis Toyota Kijang yang dipasarkan di AUTO 2000 Kotamadya Bandar Lampung pada tahun 2018

\begin{tabular}{|l|l|llll|}
\hline No & Merk & \multicolumn{4}{|l|}{ Perusahan Penyalur } \\
\hline 1 & Vios & Auto & 2000 & PT & Astra \\
\hline 2 & Alus & Auto & 2000 & PT & Astra \\
\hline 3 & Kijang inova & Auto & 2000 & PT & Astra \\
\hline 4 & Fortuner & Auto & 2000 & PT & Astra \\
\hline 5 & Avanza & Auto & 2000 & PT & Astra \\
\hline 6 & Camry & Auto & 2000 & PT & Astra \\
\hline 7 & Lain- lain & Auto & 2000 & PT & Astra \\
\hline
\end{tabular}

Sumber : AUTO2000 PT Astra Internasional Cabang Tanjung Karang. 2019

Salah satu tipe sedan yang dipasarkan oleh Auto 2000 PT Astra Internasional Cabang Tanjung Karang adalah toyota kijang. Perusaan ini terletak dijalan Raden Intan 61.A Bandar Lampung.

Harga menurut Alex S Nitisemito (2014:55)“ Harga adalah suatu barang atau jasa yang diukur dengan sejumlah uang dimana berdasrkan nilai tersebut seseorang orang perusaha bersedia melepaskan barang atau jasa yang dimiliki oleh pihak lain".

Harga adalah seorang pembeli bersedia membayar untuk suatu barang atau jasa juga merupakan nilai yang dimintak seorang penjual untuk barang yang ditawarkan untuk dijual. Umumnya harga jual produk ditentukan oleh pertimbanagn permintaan dan penawaran di pasar, sehingga AUTO 2000 PT Astra Internasional Cabang Tanjung karang dalam menentukan harga jual per unit mobil Kijang Innova berpedom dalam kebijakan harga yang di tetapkan perusahaan AUTO 2000 pusat.

Harga jual per unit di Bandar Lampung lebih tinggi dibanding dengan harga jual per unit monil kijang di Jakarta. Hal ini disebabkan harga perunit mobil kijang di Bandar Lampung dipengaruhi oleh biaya pengirim dari pusat, biaya balik nama $(\mathrm{BBN})$ dan markin laba.
Untuk melihat perkembanagn harga jual beli mobil Kijang tahun 2016 sampai dengan 2018, dapat dilihat pada tabel dibawah ini.

Tabel 2. Perkembangan Harga Jual Beli Kijang Innova Vi pada PT AUTO 2000 di Bandar Lampung (dalam jutaan rupiah ) 2016-2018

\begin{tabular}{|l|l|l|}
\hline \multicolumn{2}{|l|}{ Tahun/Semester } & Harga Jual \\
\hline 2016 & I & 119 \\
\cline { 2 - 3 } & II & 135 \\
\hline 2017 & I & 139 \\
\cline { 2 - 3 } & II & 149 \\
\hline 2018 & I & 130 \\
\cline { 2 - 3 } & II & 135 \\
\hline Rata-rata & & 137 \\
\hline
\end{tabular}

Sumber : PT AUTO 2000 ( data diolah), 2019

Berdasarkan tabel 2 diatas menunjukan harga jual mobil Kijang Innova mengalami peningkatan penjualan persemesternya sebesar 5,24\%, hal ini mengakibatkan permintaan terhadap konsumen sangat berkurang karena harja jual terlalu tinggi. Jika perusahaan menetapkan harga yang terlalu tinggi akan membuat konsumen berpikir kembali apakah produk tersebut layak untuk di beli atau tidak. Perusahaan dalam menentukan harga jual harus memiliki strategi dalam menentapkan harga jual demi pencapai tujuan dan laba maksimal.

Tabel 3. Target dan Realisasi Penjualan Mobil kijang Innova pada PT AUTO2000 Cabang Tanjung karang di Bandar Lampung 20016-2018

\begin{tabular}{|l|l|l|l|l|}
\hline $\begin{array}{l}\text { Tahun / } \\
\text { semester }\end{array}$ & $\begin{array}{l}\text { Target } \\
\text { Penjualan }\end{array}$ & $\begin{array}{l}\text { Volume } \\
\text { Penjualan }\end{array}$ & $\begin{array}{l}\text { Realisasi } \\
(\%)\end{array}$ \\
\hline 2016 & I & 100 & 95 & 95,00 \\
\cline { 2 - 5 } & II & 100 & 88 & 88,00 \\
\hline 2017 & I & 120 & 94 & 78,33 \\
\cline { 2 - 5 } & II & 120 & 89 & 74,16 \\
\hline 2018 & I & 130 & 95 & 73,68 \\
\cline { 2 - 5 } & II & 130 & 85 & 65,38 \\
\hline Rata-rata & 116 & 91 & 78,99 \\
\hline
\end{tabular}


Sumber : AUTO 2000 PT.Astra Internasional, 2019

Tabel 3, memperhatikan bahwa realisasi target penjualan berfluktusi yang cendrung menurun dengan rata-rata $91 \%$ persemester dan realisasi penjualan menenjukan penurunan dengan rata-rata $78,99 \%$ persemester.

Tabel 4. Perkembangan volume penjualan mobil kijang Innova pada AUTO 2000 di Bandar Lampung 2016-2018

\begin{tabular}{|c|c|c|c|}
\hline Tahun & & Volume & Perubahaan (\%) \\
\hline \multirow[t]{2}{*}{2016} & I & 95 & - \\
\hline & II & 88 & $(7,37)$ \\
\hline \multirow[t]{2}{*}{2017} & I & 94 & 6,82 \\
\hline & II & 89 & $(5,32)$ \\
\hline \multirow[t]{2}{*}{2018} & I & 95 & 6,74 \\
\hline & II & 85 & $(10,53)$ \\
\hline Jumlah & & & $(9,66)$ \\
\hline Rata-rata & & 91 & 1,93 \\
\hline
\end{tabular}

Sumber : AUTO 2000 PT , Astra Intrernasional, 2019

Berdasarkan tabel 4 menunjukan besarnya jumlah penjualan mobil Kijang Innova pada tahun 2016-2018 yang mengalami penurunan dengan jumlah penurunan $9,66 \%$ dengan rata-rata penurunan volume penjualan persemester sebesar $1,93 \%$ ini disebabkan karena nilai dollar menganut dan rendahnya nilai tukar rupiah.

Kebijakasanaan Saluruh Distribusi, Seluruh distribusi menurut Alex S. Nitisumoto (2013:102) mendifinisikan : "Seluruh distribusi dalah lembagalembaga distrubusi atau lembaga yang mempunyai kegiatan untuk menyalurkan barang-barang atau jasa dari produsen dan konsumen". PT AUTO 2000 dalam menyalurkan produk dapat bersipat langsung artinya konsumen membeli pada perusahaan.

Kebijakan Promosi, Menurut Basu Swasrha DH dan Ibdu Sukito (2013:222) mendifinisikan promosi: "Promosi adalah arus informasi atau persuasi satu awal yang dibaut untuk mengarah seseorang atau organisasi kedapa tindakan yang menciptakan pertukarang dalam pemasaran".

Dan melalui urauian diatas penulis merasa tertarik untuk membahas masalah ini dengan judul: " Analisis Pengaruh Harga Jual Terhadap Volume Penjualan Mobil Kijang INNOVA Vi Pada AUTO 2000 di Bandar Lampung".

\section{KAJIAN TEORI}

\section{Pengertian Manajemen}

Pengertian manajemen sangat luas dan tidak dapat di gunakan secara konsisten oleh setiap manusia. Perusahaan selalu membutuhkan manajemen-manajemen yang baik agar usaha yang di jalankannya dapat berjalan dengan teratur dan terarah untuk mencapai tujuannya. Manajemen merupakan suatu proses yang terdiri dari perencanaan, pengarahan, pengorganisasian dan pengawasan yang di lakukan untuk menentukan dan mencapai tujuan yang telah di tetapkan dengan menggunakan manusia dan sumberdaya lainnya. Menurut G.R. Terry $(2015 ; 18)$ "Manajemen adalah suatu kegiatan yang terdiri dari perencanaan, perorganisasian, pengendalian, dan pengawasan yang di lakukan untuk menentukan tujuan yang telah di tentukan."

Dari definisi tersebut disimpulkan bahwa pada dasarnya manajemen adalah suatu proses kegiatan atau usaha untuk mencapai suatu tujuan perusahaan, manajemen mengandung unsur seni karena pelaku manajemen atau manajer harus memiliki kemahiran untuk menerapkan ilmu yang dimiliki berupa konsep-konsep pada objek tertentu.

\section{Pengertian Pemasaran}

Pemasaran merupakan salah satu kegiatan-kegiatan pokok yang harus di lakukan oleh perusahaan dalam usahanya 
untuk mempertahankan kelansungan hidup pemasaran. Dan pemasaran mengandung pengertian yang sangat luas, pemasaran termasuk salah satu kegiatan Ekonomi dan merupakan salah satu fungsi yang di lakukan oleh pengusaha untuk mengembangkan perusahaan.

Berikut ini beberapa definisi pemasaran menurut para ahli:

Menurut Philip Kotler (2015:15) "Pemasaran adalah suatu proses sosial dan manajerial yang di dalamnya individu dan kelompok mendapatkan apa yang mereka butuhkan dan dinginkan dengan menciptakan, menawarkan, dan mempertukarkan produk yang bernilai dengan pihak lain.”

\section{Pengertian Manajemen Pemasaran}

Manajemen pemasaran sangat berperan penting dalam kegiatan suatu perusahaan yang tidak dapat di abaikan, dengan adanya manajemen perusahaan mengharapkan kegiatan pemasaran dapat berjalan dengan baik sesuai dengan rencana yang di harapkan. Definisi manajemen pemasaran menurut para ahli:

Philip Khotler (2013;13) "Manajemen pemasaran adalah proses perencanaan dan pelaksanaan pemikiran, penetapan harga, promosi dan penyaluran gagasan-gagasan, barang dan jasa untuk menciptakan pertukaran yang memuaskan tujuan-tujuan individu dan organisasi".

\section{Pengertian Harga Jual}

Dalam perekonomian sekarang ini bila dilihat dari sudut pandangan perusahaan harga merupakan pusat perubahan dimana yang berlaku di pasaran akan sangat mempengaruhi besrnya faktorfaktor produksi. Suatu perusahaan sebelum menetap harga tertentu untuk barang prodsinya biasanya menetapkan terlebih dahulu beberapa alternatif harga, tiap alternatif harga tersebut perusahaan memperhitungkan kemungkinan yang akan terjadi dengan harga tersebut. Berdasarkankemungkinankemungkinan ini maka perusahaan akan memiliki alternatif harga yang paling menguntungkan baik jangka pendek maupun jangka panjang. Adapun menurut ahli tentang harga jual sebagai berikut:

"Harga jual adalah moneter yang disebabkan oleh suatu unit usaha kepada pembeli atau pelanggan atas barang atau jasa untuk diserahkan"

Menurut Swasta DH (2017:11) harga adalah jumlah uang (di tambah beberapa barang kalau mungkin) yang di butuhkan untuk mendapatkan sejumlah kombinasi dari barang beserta pelayanannya.

\section{Faktor-faktor yang mempengaruhi harga}

Menurut Wiliam J Staton (2013; 316) menyatakan ada beberapa faktor yang mempengaruhi harga jual antara lain:

1. Permintaan produk

Ada dua langkah praktis dalam mempengaruhi permainan produksi yaitu:

a. Harga yang diharapkan untuk sebuah produk adalah harga yang secara sadar atau tidak sadar dinilai oleh pelanggan apakah produk mempunyai nilai yang sepadan dengan harapannya.

b. Perkiraan penjulan dengan harga yang berbeda sangat berguna bagi perusahaan apbila manejemen dapat memperkirakan beberpa voleme penjualan dan harga.

2. Target biaya pasar

Bagian pasar yang ditargetkan oleh sebuah perusahaan merupakan faktor utama yang dipakai untuk menentukan harga atau jasa yang ditawarkan.

3. Reaksi pesaing 
Pesaing baik yang sudah ada maupun yang masih potensial merupakan faktor yang mempengaruhi penting dalam menetukan harga dasar suatu produk.

4. Penggunaan strategi penetapan harga, penetrasi atau pesaing

5. Bagian lain dari bauran pemasaran

Penetapan harga saingan merupakan harga yang tinggi dalam cakupan hargaharga yang diterapkan. Penjual dapat berlanjut strategi ini untuk jangka waktu yang tidak tetapkan, atau dapat juga menurunkan harga untuk menampung sekmen lainya dalam pesar. Bagian lain dari bauran pemasaran

Harga sebuah produk sangat berpengaruhi oleh faktor apakah produk barau atau produk lama srdang berjalan dan juga fungsi kegunaan akhir produksi.

\section{METODE PENELITIAN}

\section{Objek Penelitian}

Dalam penelitian ini yang menjadi objeknya adalah : Deler Toyota AUTO 2000. Deler ini terletak di Jl. Raden Intan No 66. 2000, Enggal, Tanjung Karang Pusat, Kota Bandar Lampung. Data yang digunakan dalam penelitian ini adalah dari tahun 2016 sampai pada tahun 2019. Sedangkan pelaksanaan penelitian ini mulai bulan April sampai Agustus 2019.

\section{Metode dan Teknik Pengumpulan Data}

Data yang di perlukan dalam penelitian dapat berupa data sekunder dan data primer yang di kumpulkan dengan cara sebagai berikut :

a. Data primer

Pengumpulan data primer di lakukan melalui survey lapangan secara lansung yang di sertai dengan wawancara secara terbuka yang dilakukan dengan pegawai pada AUTO 2000 di Bandar Lampung. b. data sekunder

Mencatat data - data yang di publikasikan di AUTO 2000 di bandar lampung dalam bentuk aplikasi di lapangan yang sifatnya berkala (time series).

\section{Sampel dan Populasi}

Menurut pendapat (Suharsimi Arikunto, 2010) bahwa jika anggota populasi lebih besar dari 100 maka dapat dilakukan metode sampling dengan mengambil sampel sebesar $10 \mathrm{sd} 25 \%$ dari anggota populasi. Dengan dasar tersebut, $25 \% \times 196=49$ orang responden sebagai sampel, mewakili keseluruhan pegawai yang berjumlah 196 orang.

\section{Metode Analisis Data}

Analisisi kualitatif menggunakan pendekatan teoritis yang berhubungan dengan manajemen pemasaran, khusunya pada harga untuk menganalisis permasalahan dan mencari permasalahanya.

Analisisi kuantitatif yang dapat digunakan setelah data disajikan, maka dapat dibuat data anlisis yang bersumber data tabel Dengan rumus umum (freddy,2000 : 153 )

$$
\begin{gathered}
Y \quad=a+b x \\
a=\sum Y+b \cdot \frac{\sum X x}{n} \\
b=n\left(\sum x y\right)-\frac{\left(\sum x\right)\left(\sum y\right)}{n\left(\sum x y\right)-\left(\sum x\right) 2}
\end{gathered}
$$

Keterangan :

$\mathrm{Y}=$ variabel terikat (volume penjualan)

$\mathrm{X}=$ variabel bebes (harga jual)

$\mathrm{a} \quad=$ konstanta

$\mathrm{b} \quad=$ Koefisien korelasi 
Untuk mengetahui hubungan anatar harga jual beli dan volume penjualan di gunakan rumus korealasi, dengan rumus:

$$
\begin{aligned}
& r x y n\left(\sum x y\right)-\left(\sum x\right)\left(\sum y\right) \\
& \sqrt{n} \cdot\left(\sum x 2\left(\sum x\right) 2-n\left(\sum y 2\right)-\left(\sum y\right) 2\right.
\end{aligned}
$$

Keterangan :

$\begin{array}{ll}\sum_{\mathrm{r}^{2}} & =\text { jumlah } \\ & =\text { korelasi }\end{array}$

$\mathrm{n} \quad=$ populasi $\mathrm{x}$

$\mathrm{x} \quad=$ harga jual ( Variabel bebas )

$\mathrm{y} \quad=$ volume penjualan $($ Variabel terikat)

Bila korelasi (r) telah diketahui dapat dilihat pengaruhnya harga jual terhadap volume penjualan mobil kijang Innova Vi pada AUTO 2000.

Untuk menguji hipotesis,terlebih dahulu dicarai nilai $\mathrm{t}$-hitung, dengn rumus sebagai berikut:

$$
\frac{t . \sqrt{n}-2}{\sqrt{1-r^{2}}}
$$

Pengujian hipotesis penelitian ini dilakukan dengan membandingkan dengan

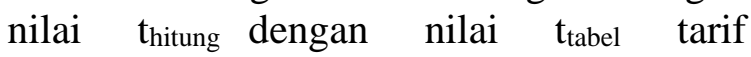
signifikasi 95\%. Ketentuan yang dipakai dalam pengujian hipotesis ini terdiri dari:

a) Jika thitung $>t_{\text {tabel }}$ dari taraf signifikan 95\% maka Ho ditolak, Hi diterima, berarti ada pengaruh signifikan.

b) Jika $t_{\text {hitung }}<t_{\text {tabel }}$ pada taraf signifikan 95\% maka Ho diterima, Hi ditolak berarti tidak ada pengaruh signifikan.

\section{HASIL DAN PEMBAHASAN}

\section{Analisis Kualitatif}

Pada umumnya perusahaan sering menghadapi permasalahan dalam melakukan kegiatanpemasarannya, yaitu kesenjangan antara harapan dan kenyataan. Dalam menyusun kenijaksanaan pemasaran digunakan analisis buruan pemasaran, yaitu yang mengkoordinasikan variabel- variabel yang terdapat dlam bauran pemasaran yang terdiair dari hara, produk, saluran distribusi, dan promosi. Keempat variabel bauran pemasaran ini dipakai oleh AUTO 2000 Astra Internasional cabang tanjung karang Bandar Lampung.

a. Kebijaksanaan produk

b. Kebijaksanaan Harga

c. Kebijaksanaan saluran distribusi

d. Kebijaksanaan promosi

Hasil pembahasan secara kualitatif ini membuktikan bahwa hipotesis yang pertama dapat diterima, yaitu bahwa AUTO 2000 PT Astra Internsional cabang Tanjung Karang belum melaksanakan kebijaksanaan pemasaran terpadu.

\section{Analisis Kuantitatif}

Rumus Persamaan Regresi

$$
Y=a+b x
$$

Dimana :

$$
\begin{gathered}
\frac{a .=y-b \sum x}{N} \\
b .=n\left(\sum x y\right)-\frac{\left(\sum x\right)\left(\sum y\right)}{n \sum x^{2}-\left(\sum x\right)^{2}}
\end{gathered}
$$

Keterangan :

$$
\begin{array}{ll}
\mathrm{X} & =\text { Harga Jual } \\
\mathrm{Y} & =\text { Volume Penjualan } \\
\mathrm{A} & =\text { Bilangan Konstanta } \\
\mathrm{B} & =\text { Koefisien }
\end{array}
$$

Berdasarkan rumus diatas, penulis menganalisa secara kuantitatif dengan berdasarkan data yang telah ada untuk dapat melihat hubungan dan mengatahui besarnya pengaruh harga jual dengan volume penjualan mobil kijang innova $\mathrm{Vi}$ pada PT. AUTO 2000 di Bandar Lampung 
Tabel Harga Jual (X) dan Volume Penjualan (Y) pada PT.AUTO 2000 di Bandar Lampung ( Dalam Jutaan Rupiah)

\begin{tabular}{|c|c|c|c|c|c|c|c|}
\hline $\begin{array}{l}\text { Tahun/ } \\
\text { Semes }\end{array}$ & & $\begin{array}{l}\text { Harga } \\
\text { (x) }\end{array}$ & jual & $\begin{array}{l}\text { Vol } \\
\text { penjualan }\end{array}$ & 2 & $\mathrm{Y}^{2}$ & XY \\
\hline 2016 & II & 119 & & 95 & 14161 & 9025 & 11305 \\
\hline & II & 135 & & 88 & 18225 & 7744 & 11880 \\
\hline 2017 & I & 139 & & 94 & 19321 & 8836 & 13066 \\
\hline & II & 149 & & 89 & 22201 & 7921 & 13261 \\
\hline 2018 & I & 130 & & 95 & 16900 & 9025 & 12350 \\
\hline & II & 159 & & 85 & 22500 & 7225 & 12750 \\
\hline Jumla & & 822 & & 546 & 113308 & 49776 & 74612 \\
\hline
\end{tabular}

Sumber : Data Diolah 2019

Dari data koefision di atas maka diperoleh data sebagai berikut :

\begin{tabular}{|c|c|r|c|}
\hline$\sum n$ & $=6$ & $\sum x^{2}$ & $=113308$ \\
\hline$\sum x$ & $=822$ & $\sum y^{2}$ & $=49776$ \\
\hline$\sum y$ & $=546$ & $\sum x y$ & $=74612$ \\
\hline
\end{tabular}

Maka perhitungannya :

$$
\begin{gathered}
b=n\left(\sum x y\right)-\frac{\left(\sum x\right)\left(\sum y\right)}{n\left(\sum x y\right)-\left(\sum x\right)^{2}} \\
b=6(76412)-\frac{(822)(546)}{6(113308)-(822)^{2}} \\
b=447672-\frac{448812}{769848-675684} \\
b=-\frac{1140}{4164} \\
b=-0,2738 \\
a=y-b x \\
=91-0,2738(137) \\
=91-37,51 \\
=53,49
\end{gathered}
$$

Dengan demikian persamaan regresi diatas dari perhitungn koefisien regresi sebagai berikut :

$$
Y=53,49-0,2738 x
$$

Pengertian dari pada a dan $b$ adalah :
1. $\mathrm{a}=53,49$ artinya : bahwa apabila variabel harga jual tidak adaperubahan maka volume penjualan yang diterima olehperusahaan adalah sebesar 53,49 unit.

$b=-0,2738$ artinya : bahwa harga jual naik sebesar Rp. 1 makaakan mengakibatkan penurunan pada volume penjualan sebesar 0,2738 unit.

\section{Uji Hipotesis}

Setelah diketahui korelasi antara harga jual dan volume penjualan pada PT AUTO 2000 di Bandar Lampung, maka berikut ini dibuktikan bahwa harga jual mempunyai hubungan negatif sangat erat dengan volume penjualan mobil merek Kijang Innova Vi pada PT. AUTO 2000 di Bandar Lampung.

Kriteria pengujian hipotesis sebagai berikut:

Ho : Tidak ada pengaruh antara harga jual dengan volume penjualan

$\mathrm{Ha}$ : Harga jual mobil kijang Innova Vi pada AUTO 2000 di bandar lampung berpengaruh negatif terhadap volume penjualan

Ha diterima apabila $t_{\text {Hitung }}>\mathrm{t}_{\text {Tabel }}$, berarti tolak Ho

Ho diterima apabila $t_{\text {hitung }}<t_{\text {tabel }}$, berikutnya tolak $\mathrm{Ha}$

Pengujian dengan menggunakan uji $\mathrm{t}$ dengan derajat kebebasan (degree of freedom)

$$
\begin{aligned}
D f & =n-k \\
= & n-2 \\
= & 6-2 \\
= & 4
\end{aligned}
$$

Sedangkan $\mathrm{t}$ tabel pada taraf signifikan $5 \%$ adalah :

$$
\begin{gathered}
t_{\text {tabel }}=t(0,05(n-2))=(0,05(6-2) \\
=0,05(4)
\end{gathered}
$$




$$
\begin{aligned}
& t_{\text {hitung }}= t \sqrt{n}-\frac{2}{\sqrt{1}-r^{2}} \\
&=-0,7602 \sqrt{6}-\frac{2}{1-0,577} \\
&=\frac{1,5204}{0,65} \\
&=-2,34
\end{aligned}
$$

Dari hasil perhitungan tersebut diperoleh nilai thitung sebesar -2,34 sedangkan ttabel 2,13 pada tingkat kepercayaan $95 \%$ dengan tingkat kesalahan $5 \%$ yang berarti bahwa t- hitung lebih besar dari t- tabel yaitu $-2,34>-2,13$ yang menyatakan bahwa hipotesis dapat di terima, yaitu harga jual tidak terpenaruh positif terhadap volume penjualan. Maka dari pengujian hipotesis tersebut maka (Ha) diterima dan menolak hipotesis nol (H0).

Dengan demikian berdasarkan hasil uji $\mathrm{t}$ maka hipotesis yang telah dirumuskan pada bab (1) yaitu " harga jual mempunyai pengaruh negatif terhadap volume penjualan mobil kijang Innova Vi pada PT. AUTO 2000 cabang tanjung karang di Bandar Lampung dapat diterima keberadaanya.

\section{KESIMPULAN DAN SARAN}

\section{Kesimpulan}

Berdasarkan hasil perhitungan
dalam pembahasan dapat disumpulkan
sebagai berikut:

1. Dari hasil perhitungan analisis regresi sederhana diperoleh persamaan $\mathrm{Y}=$ 53,49 - 0,2738X, maka dapat diperoleh pengertian bahwa $X$ (harga jual) Rp.1 maka Y (volume penjualan) akan turun sebesar 0,2738 unit

2. Dari perhitungan korelasi, diperoleh nilai rxy $=-0,7602$. Hal ini memberikan pengertian secara statistic harga jual mempunyai pengaruh negatif yang signifikan dengan volume penjualan mobil kijang innova $\mathrm{Vi}$ pada
PT. AUTO 2000 Cabang Tanjung Karang di Bandar Lampung.

3. Harga jual mempunyai hubungan yang negatif dengan volume penjualan mebil kijang innova Vi pada PT. AUTO 2000 Cabang Tanjung Karang di Bandar Lampung, yang didukung oleh hasil uji - $\mathrm{t}$ yang diperoleh sebesar -2,34 sedangkan nilai tabel pada tingkat kepercayaan $95 \%$ dengan derajat kebebasan 5\% diperoleh nilai $t_{\text {tabel }}$ sebesar 2,13. Oleh karena itu nilai thitung lebih besar dari pada $t_{\text {tabel}}$, berarti $\mathrm{Ha}$ diterima dan Ho ditolak.

Dengan demikian hipotesis yang menyatakan bahwa harga jual mempunyai pengaruh negatif terhadap volume penjualan dapat diterAima keberanarannya.

\section{Saran}

Berdasarkan perhitungan dan pembahasan dapat diambil beberapa saran yang diharapkan dapat menjadi masukan yang bermanfaat bagi perusahaan yaitu sebagai berikut:

1. Untuk meningkatkan volume penjualan perusahaan hendaknya pimpinan perusahaan dapat meninjau kembali harga jual mobil kijang innova Vi yang telah ditetapkan agar dapat bersaing dengan produk yang sejenisnya.

2. PT. AUTO 2000 perlu mengadakan survey atau penelitain-penelitian secara periodek terhadap konsumen yang membeli produk mobil perusahaan apakah mereka puas dengan pelayanan dan harga yang ditawarkan melalui keaktifan dari personal selling perusahaan.

3. Menetapkankebijaksanaanpemasaran secaraterpadudengan 
memperhatikankebijaksanaan harga jual yang akan dipakai.

Kebijakasanaan harga jual berdasarkan pelaku pasar dapat diterapkan dengan cara menetapkan harga jual yang relatif murah atau sama dengan pesaing.

\section{DAFTAR PUSTAKA}

Alex Nitisemito, 2013, Marketing,Jakarta: Ghalia Indonesia.

Basu Swsta, Irawan 2014. Manajemen Pemasaran Modern Edisi Kedua. Yogyakarta: Liberty.

J, Supranto. 2014. Statistik Teori dan Aplikasi III. Jakarta: Erlangga.

Adi, Zakaria Afif.2014. Manajemen. Analisis Perencanaan Implementasi Dan Pengendalian. Edisi Ketujuh. Jakarta: Fakultas Ekonomi Universitas Indonesia.

Radiusono, 2014. Intisari Manajemen Pemasaran. Bandung: Penerbit Remaja Karya.

Sudjana, 2015.Metode Statistik, Edisi Kelima, Bandung: Tarsito.

Sumarsono, S.R. 2015. Strategi Pemasara. Bandung:CV Mandur Maju.

William, J Stanton. 2015. Prinsip Pemasaran, Jilid II Edisi ke Tujuh,Terjemahan Sadu Sundaru dan Yohanes Lamarto.Jakarta: Erlangga.

G.R, Terry. 2015, Dasar-dasar Manajemen, Edisi Revisi. Jakarta:Buku Beta.
Bruce J, Walker. (2014; 221). Sales Promotion, Jilid II.Jakarta: Penerbit Erlangga.

Grogoruis, Chandra. (2015;155). Pemasaran Sentrategij, Edisi II. Jakarta: ISBN.

Simamora, Henry. 2003. Manajemen Sumber Daya Manusia. Edisi 1. Yogyakarta: $\quad$ STIE $\quad$ YKPN Yogyakarta. 